\title{
ИСТОРИЯ
}

УДК / UDC 94(47).065-066

DOI: $10.22162 / 2500-1523-2021-2-248-259$

\section{Католический врач для калмыцкого хана: к характеристике вероисповедной политики на южных окраинах Российской империи (начало 60-х гг. XVIII в.)}

\author{
Андрей Сергеевич Ряжев 1
}

${ }^{1}$ Калмыцкий научный центр РАН (д. 8, ул. им. И. К. Илишкина, 358000 Элиста, Российская Федерация) кандидат исторических наук, ведущий научный сотрудник

0000-0002-2626-6953. E-mail: ryazhevas@kigiran.com

(C) КалмНЦ РАН, 2021

(C) Ряжев А. С., 2021

Аннотация. Введение. Статья посвящена вероисповедной политике Российской империи в раннее Новое время. Впервые в историографии изучена деятельность католических миссионеров касательно Калмыцкого ханства, попытки ордена капуцинов наладить контакты с калмыцким ханом Дондук-Даши. Материаль и методы. Исследование основано на преимущественно неопубликованных материалах политико-дипломатической переписки Коллегии иностранных дел и законодательстве первой половины 60-х гг. XVIII в., характеризующих методы и территориальный размах деятельности миссионеров, в частности, их проникновение в калмыцкую степь. Методология исследования определена структурно-функциональным подходом к изучению системы государственных органов России. В сочетании с подобным подходом использован историко-генетический метод, оптимальный для понимания изменений во властной системе Российской империи начала - первой половины 60-х гг. XVIII в. Результаты. Показаны причины стремления ордена капуцинов на Северный Кавказ и место Калмыцкого ханства в миссионерских планах, стандартные, свойственные эпохе приемы миссионеров для воздействия на некатолическое население. Установлено, что капуцины, опираясь на поддержку австрийской дипломатии, обходили формальные ограничения миссионерской деятельности в регионе, что не могло не вызывать вероисповедных трений. Прослежена деятельность российских учреждений по урегулированию расхождений такого рода, выявлены трудности, с которыми сталкивалось начальство разных уровней в связи с потребностью в соответствующем урегулировании. При этом подчеркнуто, что конкретные интересы светских и духовных органов здесь не совпадали, что имело на юге давнюю и устойчивую традицию. Обозначена динамика российского отношения к миссионерам на юге. Если в условиях «австрийской системы» - ориентации на австрийский двор, сохранявшейся в российской дипломатии с петровских времен и при Елизавете Петровне, их положение было благоприятным, то после воцарения Екатерины II и наступившего затем некоторого российско-австрийского охлаждения возможности миссионеров на Северном 


\title{
История
}

Кавказе и в калмыцкой степи существенно ограничивались. Автор констатирует, что в процессе снятия вероисповедных разногласий российские власти в начале 1760-х гг. столкнулись со слабостью законодательной базы и по части неправославных религий, и в целом. Решение проблемы наметилось с воцарением Екатерины II и ее политикой в сферах религии и права.

Ключевые слова: Российская империя, раннее Новое время, Елизавета Петровна, Екатерина II, южные окраины России, Северный Кавказ, Калмыцкое ханство, католические миссионеры, капуцины, российско-австрийские отношения, вероисповедная политика, правовая политика

Благодарность. Исследование проведено в рамках государственной субсидии - проект «Комплексное исследование процессов общественно-политического и культурного развития народов Юга России» (номер госрегистрации: АААА-А19-119011490038-5).

Для цитирования: Ряжев А. С. Католический врач для калмыцкого хана: к характеристике вероисповедной политики на южных окраинах Российской империи (начало 60-х гг. XVIII в.) // Монголоведение. 2021. № 2. C. 248-259. DOI: 10.22162/2500-15232021-2-248-259

\section{Catholic Physician for Kalmyk Khan: Characterizing Imperial Russia's Religious Policy in Its Southern Peripheries, Early 1760s}

\author{
Andrey S. Ryazhev ${ }^{1}$
}

${ }^{1}$ Kalmyk Scientific Center of the RAS (8, Ilishkin St., 358000 Elista, Russian Federation) Cand. Sc. (History), Leading Research Associate

iD 0000-0002-2626-6953. E-mail: ryazhevas@kigiran.com

\author{
(C) KalmSC RAS, 2021 \\ (C) Ryazhev A. S., 2021
}

\begin{abstract}
Introduction. The article concentrates on the religious policy of the Russian Empire in the Early Modern Time. For the first time in historiography, a study was carried out concerning the activities of Catholic missionaries in relation to the Kalmyk Khanate, the attempts of the Capuchin Order to establish contacts with the Kalmyk Khan Donduk-Dashi. Materials and methods. The study is based on mostly unpublished materials from the political and diplomatic correspondence of the Collegium of Foreign Affairs and the legislation of the first half of the $1760 \mathrm{~s}$, characterizing the methods and territorial scope of the missionaries activity, in particular, their penetration into the Kalmyk steppe. The methodology of the study has been determined by the structural and functional approach to the system of state bodies of Russia. In combination with this approach, a historical-genetic method was used, which is optimal for the study of changes in the power system of the Russian Empire from the beginning of the $18^{\text {th }}$ century through the first half of the $1760 \mathrm{~s}$. Results. The section demonstrates the reasons for the aspiration of the Capuchin Order to the North Caucasus and the place of the Kalmyk Khanate in missionary plans, describes the standard epoch-specific missionary techniques for influencing the non-Catholic population. It has been determined that the Capuchins, relying on the support of Austrian diplomacy, bypassed the formal restrictions on missionary activity in the studied region, which could not but cause religious friction. The activity of Russian institutions to resolve differences of this kind is traced, the difficulties encountered by the
\end{abstract}


authorities in the capital and especially at the local level in connection with the need for an appropriate settlement are shown. At the same time, it is emphasized that the specific interests of secular and spiritual bodies in such cases did not coincide, which had a long-standing and stable character in the south. The dynamics of the attitude of the Russian authorities towards missionaries in the Russian south is outlined. If under the conditions of the "Austrian system" orientation towards the Austrian court, which had been in Russian diplomacy since the times of Peter the Great and under Empress Elizaveta Petrovna, their position was favorable, then after the accession of Catherine II and the crisis in Russian-Austrian relations, the possibilities of missionaries in the North Caucasus and the Kalmyk steppes were significantly limited. The author states that in the process of settling religious tensions, the Russian authorities in the early 1760 s faced a weak legal framework both in relation to non-Orthodox religions and in general. The solution to the problem was outlined with the accession of Catherine II and in connection with the empress's policy in the spheres of religion and law.

Keywords: Russian Empire, Early Modern times, Empress Elizaveta Petrovna, Catherine II, the southern outskirts of Russia, North Caucasus, the Kalmyk khanate, Catholic missionaries, Capuchins, Russian-Austrian relations, religious policy, law policy

Acknowledgements. The reported study was funded by government subsidy - project name 'Sociopolitical and Cultural Development of South Russia's Peoples: Comprehensive Studies in Respective Processes' (state reg. no. AAAA-A19-119011490038-5).

For citation: Ryazhev A. S. Catholic Physician for Kalmyk Khan: Characterizing Imperial Russia's Religious Policy in Its Southern Peripheries, Early 1760s. Mongolian Studies (Elista). 2021; 13(2): 248-259. (In Russ.). DOI: 10.22162/2500-1523-2021-2-248-259

\section{Введение}

Российская вероисповедная политика - актуальный вопрос историографии истории раннего Нового времени [Ряжев 2006: 84]. Важным его аспектом, требующим специального изучения, выступает отношение властей к европейцам-миссионерам. Складывание к XVIII в. новой сети торговых путей, возникновение ранее неизвестных способов и акторов взаимодействия европейских держав с остальным миром оказали влияние на христианское миссионерство, усилив, в частности, его движение в восточном направлении. При этом основными проводниками христианства вне Европы по-прежнему выступали католические монашеские ордены. Россия, шагнувшая по пути европеизации, вызывала у них большой интерес. В понимании европейцев она была территорией условно безопасного транзита в Центральную Азию и Индию. Кроме того, российские окраины, близкие к регионам давнего европейского миссионерства - Святой земле, Персии, Закавказью или сопредельные с ними, населялись народами, в отношении которых возникали миссионерские намерения. Однако столь широкие планы входили в противоречие с прерогативами православного исповедания и прерогативами правившей греко-российской церкви и порождали соответствующие конфликты. Конфликты носили не только религиозный, но и дипломатический характер, поскольку представителей тех или иных орденов вне Европы патронировали крупнейшие европейские католические державы. От российских светских органов в центре и на местах требовались усилия для разрешения подобных несогласий. Расхождения возникали не только в сфере дипломатии, но и внутренней политики, ибо мнения светских и духовных учреждений в процессе снятия вероисповедных трений не всегда совпадали. 


\section{История}

Задачей властей становился поиск эффективных инструментов в урегулировании процессов в духовной области. Цель статьи - анализ деятельности католических миссионеров касательно Калмыцкого ханства, освещение попытки ордена капуцинов наладить контакты с калмыцким ханом Дондук-Даши.

\section{Материалы и методы}

В качестве источника привлечены документы Коллегии иностранных дел, хранящиеся в Архиве внешней политики Российской империи. Это, прежде всего, переписка коллегии с Астраханской губернской канцелярией по поводу спора между капуцинами-миссионерами и армяно-григорианской общиной Астрахани во второй половине 1750 - начале 1760-х гг. и последовавших за ним жалоб греко-российского астраханского епископа на миссионеров. Использованы также коллежские материалы о вмешательстве в дело посла Австрийской монархии, оказывавшего поддержку миссионерам [АВПРИ. Ф. 10. Оп. 10/1. Д. 1 (1759-1761); АВПРИ. Ф. 10. Оп. 10/1. Д. 1 (1760); АВПРИ. Ф. 10. Оп. 10/1. Д. 1 (1762)].

В целом документы раскрывают методы и территориальный размах деятельности миссионеров, в частности, их проникновение в калмыцкую степь и города Северного Кавказа - Кизляр и Моздок, контактов миссионеров с властями и конфессиями в условиях господства во внешнем курсе России «австрийской системы» - ориентации на австрийский двор, и в данной связи значение источников трудно переоценить.

Существенным дополнением к неопубликованным документам является публикация бумаг высших российских органов управления о католических миссионерах на Северном Кавказе, освещающих динамику подходов государства к миссионерской работе иноземцев [Русско-осетинские 1984].

Методология исследования определена структурно-функциональным подходом к системе государственных органов России. В его рамках обеспечено понимание различий между формальной специализацией и фактической компетенцией учреждений, задействованных в сфере вероисповедной политики в центре и на местах. В сочетании с подобным подходом оправдано применение историко-генетического метода, оптимального для понимания изменений во властной системе Российской империи начала - первой половины 60-х гг. XVIII в.

\section{Австрийские капуцины в калмыцкой степи}

\section{Цель - Северный Кавказ}

Вторая половина 1750-х гг. отмечена крупным и длительным конфликтом между миссионерами - представителями ордена капуцинов и астраханскими армяно-григорианами, с одной стороны, и теми же капуцинами и астраханскими властями - с другой.

В дореволюционной отечественной историографии названный сюжет изучался с позиции истории права [Кузнецов 1898: 75-93] и истории Церкви [Саввинский 1900: 30-38; Саввинский 1902; Саввинский 1903: 112, 113, 240, 241], кроме того, деятельность миссионеров - его участников подвергалась официозно-монархической критике [Толстой 1876: 173-179]. 
В наши дни астраханский эпизод получил трактовку в плане европеизации России в Новое время, развития в ней европейского христианства [Андреев 2010: 8, 9]. В целом тема католического миссионерства в России периода Нового времени сводится в современной научной литературе к межкультурному взаимодействию [Андреев 2014: 8-11; Янгель, Оглезнева 2016: 209, 210].

К вопросу о католической миссии в Астрахани и - шире - России обращаются и современные церковные авторы, принадлежащие к разным христианским конфессиям. Опыты такого рода на сегодня едва ли можно считать удачными [Мацкевич 2012: 14-65; Кальченко 2018: 157, 158], однако попытки проводить параллели и намечать сходство между миссионерскими моделями, которым католические ордены следовали на Востоке и в России, вполне оправданы [Максимов 2018: 20-22].

Что касается проблематики армяно-католического исповедания, то она введена в контекст истории армянского этноса в России и вне ее [Чолакян 2012: 55 , 56, 60, 61; Амбарцумов 2012: 86-88, 92, 93], с позиции которой астраханские перипетии середины XVIII в. предстают лишь малозначительным эпизодом.

Одной из причин, вызвавших к жизни тогдашний спор между миссионерами и губернской канцелярией, стала невыдача паспортов миссионерам для поездок за пределы Астрахани. В условиях австрийского дипломатического давления в него пришлось включиться Коллегии иностранных дел, советовавшей астраханской администрации пойти навстречу миссионерам и впредь не чинить препятствий в получении проездных документов. Рекомендация не отвечала позиции Церкви, но светские власти в угоду дипломатической конъюнктуре не обращали на это внимания. Впрочем, для южного региона ничего экстраординарного - похожие ситуации возникали здесь и раньше, и позже [Толстой 1876: 173; Ряжев 2017: 33-35].

Капуцины смогли воспользоваться предоставленной свободой. В целом миссионеры-католики обосновались на Среднем Востоке издавна, и посему очередным шагом для них было освоение Кавказа. Территории Южного Кавказа (Закавказья), главным образом, Грузии сделались вотчиной французских миссионеров. Австрийские миссионеры проникли сюда позже, сделав ставку на армян в грузинских городах. Монахи-австрийцы сделали главной целью Северный Кавказ, утвердиться на котором они предполагали опять-таки путем проникновения в армянскую среду и формирования в российских городах близ южных границ армяно-католических общин.

Интерес капуцинов к Северному Кавказу был действительно заметен. Российские власти в процессе урегулирования конфликта между армянами и капуцинами рассматривали также обвинения капуцинов в том, что они привлекли в католичество и православных российских подданных. Перед лицом подобных обвинений капуцин Ф.-М. Сотер, один из участников тяжбы и глав капуцинской миссии в Астрахани, осенью 1756 г. заявил о желании выехать из России. Но даже в качестве подследственного, то есть понимая угрозу, возникавшую для него, он хотел покинуть пределы государства не иначе, как предварительно побывав именно на Северном Кавказе и уже оттуда направиться в Турцию [Ряжев 2020: 11], да и его сотоварищи, оставшиеся в Астрахани, как сказано выше, неоднократно требовали паспорта для выезда в Кизляр. 


\section{История}

Капуцинская методика проникновения на Северный Кавказ отличалась многомерностью. Прощупывая подступы к цели, патеры изучали обстановку и в степи и смогли наладить отношения с Калмыцким ханством. Для этого использовался один из стандартных миссионерских приемов - оказание медицинской помощи. Иезуиты в свое время применяли его в Тибете [Beltramini 2021: 69, 70]. Капуцины в калмыцкой степи от них не отставали.

В 1760 г. патер Рамолдус просил в Астраханской губернской канцелярии разрешения «по требованию калмыцкого хана Дондук-Даши... для лечения в калмыцких улусах больных к нему, хану, съездить позволить, и лекарствы... из здешней аптеки за денги его собственные или ханские отпустить...», да и впредь по требованию хана не запрещать степных визитов [АВПРИ. Ф. 10. Оп. 10/1. Д. 1 (1759-1761). Л. 780б., 79].

В ответ из гарнизонной аптеки донесли, что отпускать медикаменты Рамолдусу и принимать его рецепты для изготовления снадобий «не велено». К тому же врач из патера весьма посредственный, «ибо он, как видно из ево рецептов, в теори[и] медической невеликое основание имеет», посему лекарств ему давать не стоит во избежание вреда больным - и калмыкам, и прочим. Настырный капуцин обошелся, впрочем, и без казенных медикаментов. В итоге астраханские власти дали ему санкцию на выезд в степь, подразумевая и настоятельное ханское пожелание, и высказанную ранее рекомендацию Коллегии иностранных дел [АВПРИ. Ф. 10. Оп. 10/1. Д. 1 (1759-1761). Л. 79, 79об.]. Тактика капуцинов, таким образом, себя вполне оправдывала.

Российская политика конца 1750 - первой половины 1760-х г2. в отношении посланцев «Венгеро-Богемского королевства»: смена вех

Подобная тактика могла бы носить еще более успешный характер при сохранении традиции покровительственного отношения к миссионерам, основанной астраханским губернатором А. П. Волынским в начале XVIII в. Однако с середины столетия здесь назревали изменения.

В свое время, в разгар конфликта между капуцинами и армяно-григорианами, третейским судьей в нем выступал астраханский архимандрит Мефодий, тем самым соприкоснувшийся с вопросом о миссионерах в Астраханской епархии. Через несколько лет, будучи в сане правящего архиерея, Мефодий провел свое расследование по поводу присутствия капуцинов.

Его результаты отложились в промемории Астраханской консистории в Астраханскую губернскую канцелярию и канцелярском доношении Астраханской губернской канцелярии в Коллегию иностранных дел от 27 января 1761 г. Из последнего документа вытекает, что преосвященного весьма тревожила активность католических эскулапов: он опасался, что они возымеют успех не только у калмыков, но и у русских. «В сообщенной в губернскую канцелярию из духовной преосвященного Мефодия, епископа Астраханского и Ставропольского консистори[и] промемори[и], — гласило доношение - написано, известно де Его Преосвященству учинилось, что прибывшие пред недавним временем незнаемо откуда в Астрахань римского исповедания патеры два человека, о именах их неизвестно, жителство имев при построенном здесь римском костеле, о превращении в свой их закон из разных иноверцов стараются неусыпно, и притом, ходя по дворам, не токмо иностранному народу, но по невежеству 
и российским несведущим силы и Писания немощным людем, находящимся в различных болезнях, не дав прежде о себе Его Преосвященству знать, производят, получая неведомо где, лекарствы, а о ползе того их якобы врачества, дабы оные между тем не могли и от православные веры кого отторгнуть, есть не без сумнения...» [АВПРИ. Ф. 10. Оп. 10/1. Д. 1 (1759-1761). Л. 75, 75об.].

Епископ не упустил также случая поставить под сомнение пребывание католиков в Астрахани вообще. «... К тому же не токмо оным патерам, хотя б из них одному, - продолжал преосвященный, — но и костелу их в Астрахани, что здесь природных римлян, кроме превращенных, как по справкам з губерниею оказалось, почти никого не имеется, быть не у чего; о чем в силе указов и Святейшему Правительствующему Синоду со мнением от Его Преосвященства представлено...». Как следствие, владыка Мефодий в промемории потребовал от канцелярии установить правомерность нахождения миссионеров в Астрахани [АВПРИ. Ф. 10. Оп. 10/1. Д. 1 (1759-1761). Л. 75-75об., 88-89об.].

Астраханская губернская канцелярия на просьбу архиерея откликнулась и вопрос изучила. Капуцинов-докторов оказалось не двое, как думал преосвященный, а трое - патер Канутус, патер Кресениус и уже известный нам патер Рамолдус. Они были допрошены и дали объяснение причин приезда и содержания деятельности в России. В частности, они сообщили, что прибыли через Польшу из «Венгеро-Богемского королевства», имея паспорта, которые им выдали «Мари Терези», тамошняя государыня, и Г.-К. Кайзерлинг, русский посол в Вене, «приезд же их (миссионеров. - А. Р.) в Россию последовал по указу римского папы». В Россию они, выехав из Вены и достигнув Варшавы, добирались затем разными путями: Канутус избрал Кенигсберг, Кресениус Люблин и Белую Церковь, Рамолдус — Митаву.

Канутус и Рамолдус по прибытии в Санкт-Петербург явились в Коллегию иностранных дел и затем двинулись в Москву, Кресениус в северной столице не побывал: миновав Киев, он сразу направился в Москву. В итоге все трое обосновались в Астрахани «з данными им от находящегося в Москве римского католицкого монастыря префектов пропускными писмами, также от глуховского коменданта генерал-майора Ивана Делатура, царицынского коменданта полковника Чистюнина и из Лифляндской генерал-губернаторской канцелярии пашпортами» [АВПРИ. Ф. 10. Оп. 10/1. Д. 1 (1759-1761). Л. 75об.-76, 81-84].

Показания миссионеров знаменательны, ибо в них обозначены силы, продвигавшие капуцинов на южнороссийскую границу, - папство и австрийская императрица Мария-Терезия. Не случайно здесь фигурирует и посол Кайзерлинг: сторонник русско-австрийского сближения, адепт «австрийской системы», он в течение ряда лет обеспечивал документами для поездок в Россию миссионеров, чьими патронами выступали австрийские Габсбурги. Ту же функцию в отношении проезжавших через украинские земли миссионеров выполнял и генерал И. Делатур (правильно: де ла Тур), занимавший важный пост коменданта г. Глухова - одной из резиденций украинского гетмана [Ряжев 2020: 13, 14].

Нарушений за патерами не нашлось, и их отпустили, обязав подписками о запрещении миссионерской работы среди российских подданных. В дальнейшем они продолжили миссионерствовать в Астрахани и посещать калмыков (по крайней мере, до смерти хана Дондук-Даши). Канутус заявлял о необходимости 


\section{История}

поездки «для монастырских нужд» в Кизляр и Моздок [АВПРИ. Ф. 10. Оп. 10/1. Д. 1 (1759-1761). Л. 76]. Местные власти противились этому: канцелярия сделала запрос в консисторию, та ответила, что без указа Св. Синода дать позволение не может, но в принципе выезд нежелателен по духу указов центральных учреждений, появившихся в период расследования капуцино-армянского конфликта и запрещавших капуцинам миссионерство в отношении российских подданных. В этой связи канцелярия заключила, что Канутуса в Кизляр не отпустит по той причине, что он не являлся в «главный российский коллегиум», к тому же ни он, ни другие капуцины-лекари своего приезда в канцелярии с момента прибытия в Астрахань «не объявляли». Что касается врачебной деятельности капуцинов, то она разрешалась лишь Рамолдусу и только по просьбе хана Дондук-Даши, но не для более широкого контингента страждущих [АВПРИ. Ф. 10. Оп. 10/1. Д. 1 (1759-1761). Л. 78].

Проблему неопределенности статуса капуцинов-миссионеров на юге ухватила австрийская дипломатия, оказывая давление на российское внешнеполитическое ведомство и пытаясь добиться фиксации их фактических свобод. Подобные вопросы стали предметом конференции, которую в январе 1761 г. провели «цесарский» посол Эстергази и канцлер М. И. Воронцов. Канцлер, признавая важность союза с Австрийской монархией, пошел на уступки. В частности, он согласился с необходимостью строительства каменных храмов для католиков в городах, где пребывание миссионеров было давним, а католические общины отличались устойчивостью - в Москве, Астрахани, Нежине [АВПРИ. Ф. 10. Оп. 10/1. Д. 2 (1760). Л. 47-49].

Однако и в рамках российской политико-правовой надстройки с середины 1750-х гг. продвигалось осознание потребности упорядочить законы о миссионерах и установить правила сообщений миссионеров с властями и духовными институциями на территории империи. Затруднения, с которым приходилось сталкиваться, четко обозначались в донесении Астраханской губернской канцелярии в Коллегию иностранных дел от 27 января 1761 г.

С одной стороны, говорилось в документе, по итогам расследования канцелярия вынуждена «при том объявить, хотя оная консистория того промемориею и требует, надлежит ли тем капуцинам впредь в Астрахани быть, от губернской канцелярии мнения, но понеже указом Святейшего Правительствующего Синода, присланном к Его Преосвященству, велено за оными духовными смотрение иметь Его Преосвященству, почему губернская канцелярия об них и мнения своего предписать не может, а все оное зависит в разсмотрени[и] Его Преосвященства...» [АВПРИ. Ф 10. Оп. 10/1. Д. 1 (1759-1761). Л. 78].

С другой стороны, врачебная деятельность капуцинов, их обращения в аптеку, вояжи в калмыцкие улусы вызывают потребность в однозначном указе сверху об их статусе в отношении светских властей на местах, «а особливо ж как их генерално именовать (ибо они домогаются всегда называть себя патерами, яко всем отцами)», но «команде архиерейской» подлежать отнюдь не хотят [АВПРИ. Ф 10. Оп. 10/1. Д. 1 (1759-1761). Л. 79об.].

Поиски подходов к разрешению правовой коллизии осложнялись наличием «австрийской системы». Подвижка наметилась только после воцарения Екатерины II и отказа от однобокой ориентации на Австрию. На Северном Кавказе с 
1745 г. действовала Осетинская духовная комиссия [Кидирниязов, Лысенко 2015: 164-166]. Ее задачей было создание прослойки крещеных горцев. Позже планировалось формирование на их основе новой сословной группы, аналогичной Ставропольскому корпусу крещеных калмыков, возникшему в результате распространения православия среди калмыков и, в меньшей степени, деятельности первой (кочевой) калмыцкой миссии [Саввинский 1903: 226-230; Джунджузов, Любичанковский 2017: 176-180].

На Северном Кавказе с 1760-х гг. отмечался рост российской активности, соответственно, об уступке католикам потенциального военно-служилого резерва не могло идти и речи. Вероисповедная либерализация, объявленная Екатериной II, предполагала свободу «пристойным образом склонять в Христианские законы» окраинных «магометан», других иноверцев и фиксировалась, в частности, шестым пунктом Манифеста от 22 июля 1763 г. [ПСЗ 1830: 314].

Однако право предоставлялось лишь иностранным колонистам на обживаемых ими землях, но не миссионерам, посему миссионерская активность на Северном Кавказе при Екатерине II подверглась ограничению. Указом от 29 августа 1765 г. Коллегия иностранных дел предписала кизлярскому коменданту «немедленно выжить» двух католических миссионеров, незадолго до того прибывших «в киштинской народ», «да и впредь подобных отнюдь не допускать», обязав и киштинских старшин в дальнейшем не принимать таких миссионеров. На этом же настаивал и Синод в указе от 28 сентября 1765 г. о реорганизации Осетинской комиссии [Русско-осетинские 1984: 34-36].

\section{Заключение}

Формальные ограничения деятельности католических миссионеров на юге в раннее Новое время существовали всегда, но со времен губернаторства А. П. Волынского значительно утратили актуальность для европейцев. Расследование Астраханской консистории показало, что капуцины легко преодолевали подобные ограничения и позже, когда традиция покровительства и индифферентизма исчерпала свое действие: медицина и «монастырские нужды» служили прикрытием для миссионеров, а дипломатическая поддержка стимулировала их активность. Как следствие, неизбежными становились вероисповедные трения, как неизбежным оказывалось и нарушение прерогатив греко-российской церкви. Оно не было для властей критичным, однако в свете дипломатических конфликтов необходимость более детальной регламентации неправославного миссионерства проявлялась все более отчетливой. В этой связи констатация Астраханской губернской канцелярии - «велено за оными духовными смотрение иметь Его Преосвященству, почему губернская канцелярия об них и мнения своего предписать не может...» - подчеркнула слабость российской правовой базы как в отношении неправославных религий, так и в целом. Решение проблемы наметилось с воцарением Екатерины II и ее законодательной работой 60-80-х гг. XVIII в. в духе «просвещенного абсолютизма».

\section{Источники}

АВПРИ - Архив внешней политики Российской империи.

ПС3 - Полное собрание законов Российской империи. Собрание 1-е (с 1649 по 12 декабря 1825 г.). СПб.: Тип. 2-го Отд-ния Собств. Е. И. В. канцелярии, 1830. Т. 16 : С 28 июня 1762 г. по 1764 г. 1018, 106 с. 


\section{История}

Русско-осетинские 1984 - Русско-осетинские отношения в XVIII веке: сборник документов: в 2-х тт. Т. 2. 1764-1784 / сост. М. М. Блиев. Орджоникидзе: Ир, 1984. 439 c.

\section{Sources}

Archive of Foreign Policy of the Russian Empire.

Bliev M. M. (comp.) Russian-Ossetian Relations, $18^{\text {th }}$ Century: Collected Documents. In 2 vols. Vol. 2: 1764-1784. Ordzhonikidze: Ir, 1984. 439 p. (In Russ.)

First Complete Collection of Laws of the Russian Empire. St. Petersburg: His Own Imperial Majesty's Chancellery (Second Section), 1830. Vol. 16: 28 June 1762 to 1764. 1018 p. (In Russ.)

\section{Литература}

Амбарцумов 2012 - Амбариумов И. В. Армяно-католический вопрос в Российской империи в начале ХХ в. // Христианское чтение. 2012. № 4. С. 84-105.

Андреев 2010 - Андреев A. Н. Российские «инородцы» в XVIII веке и западно-христианское влияние // Вестник Южно-Уральского государственного университета. Серия: Социально-гуманитарные науки. 2010. Вып. 15. № 28 (204). С. 6-11.

Андреев 2014 - Андреев А. Н. Духовенство римско-католической церкви в Греческой слободе Санкт-Петербурга // Вестник Южно-Уральского государственного университета. Серия: Социально-гуманитарные науки. 2014. Т. 14. № 4. С. 6-14.

Джунджузов, Любичанковский 2017 - Джунджузов С. В., Любичанковский С. В. Миссионерская деятельность Никодима Ленкеевича в Калмыцком ханстве (17251734 годы) // Новый исторический вестник. 2017. № 3 (53). С. 172-191.

Кальченко 2018 - Алексей Кальченко, свящ. История возникновения и развития католических монашеских миссий в России // Труды Белгородской духовной семинарии. Белгород: ЛитКараВан, 2018. Вып. 7. С. 154-162.

Кидирниязов, Лысенко 2015 - Кидирниязов Д. С., Лысенко Ю. М. Осетинская духовная комиссия на Северном Кавказе в XVIII - первой половине XIX в. // Вопросы истории. 2015. № 3. С. 163-169.

Кузнецов 1898 - Кузнецов Н. Д. Управление делами иностранных исповеданий в России в его историческом развитии // Временник Демидовского юридического лицея, 1898. Кн. 75. С. 65-104.

Максимов 2018 - Максимов А. С. От этноцентризма к инкультурации. Культура и цивилизация в истории католических миссий // Вестник Православного Свято-Тихоновского гуманитарного университета. Серия I: Богословие. Философия. 2015. № 5 (61). С. 9-26.

Мацкевич 2012 - Мацкевич, Вальдемар (OFM Conv). История Католической Церкви на Астраханской земле. Астрахань: Тип. «Новая Линия», 2012. 245 с.

Ряжев 2006 - Ряжев А. С. Вероисповедная политика русского «просвещенного абсолютизма»: история изучения // История и историки: историографический вестник / отв. ред. А. Н. Сахаров. М.: Наука, 2006. С. 84-126.

Ряжев 2017 - Ряжев А. С. Неопубликованные документы 1777 г. об отсылке крещеного пленника бакинскому хану (из переписки Св. Синода и Коллегии иностранных дел) // Magna adsurgit: historia studiorum. 2017. № 1. С. 32-40.

Ряжев 2020 - Ряжев A. С. Великая княгиня Екатерина Алексеевна и католики-миссионеры на юге России: будущая императрица в поисках путей к власти (вторая половина 1750-х годов) // Новый исторический вестник. 2020. № 2. С. 6-22.

Саввинский 1900 - Иоанн Саввинский, свящ. Армяне в Астраханской епархии и отношение к ним местных архипастырей в XVIII в. Астрахань: тип. В. Л. Егорова, 1900. [2], $106 \mathrm{c}$. 
Саввинский 1902 - Иоанн Саввинский, свящ. Католики и лютеране в Астраханской епархии и отношение к ним Св. Синода и местной епархиальной власти. Астрахань: тип. В. Л. Егорова, 1902. 61 с.

Саввинский 1903 - Иоанн Саввинский, свящ. Историческая записка об Астраханской епархии за 300 лет ея существования (с 1602 по 1902 год). Астрахань: тип. В. Л. Егорова, 1903. 403, [2] с.

Толстой 1876 - Толстой Д. А. Римский католицизм в России: историческое исследование графа Дмитрия А. Толстого. Т. 1. СПб.: Изд. и тип. В. Ф. Демакова, 1876. VIII, $538 \mathrm{c}$.

Чолакян 2012 - Чолакян $A$. Сирийские католики армянского происхождения // 21-й век: Информационно-аналитический журнал. 2012. № 2 (22). С. 53-68.

Янгель, Оглезнева 2016 - Янгель Т. Я., Оглезнева Г. В. Мотивы прозелитизма в межконфессиональных отношениях во второй половине XIX в. в России // Известия Иркутского государственного университета. Серия: Политология. Религиоведение. 2016. Т. 18. С. 204-211.

Beltramini 2021 - Beltramini E. Roman Catholic Government and Mission to Tibet: A Historical and Theological Study // International Bulletin of Mission Research. 2021. Vol. 45. Is. 1. Pp. 68-72.

\section{References}

Ambartsumov I. V. The Armenian-Catholic issue in the Russian Empire in early $20^{\text {th }}$ century. Christian Reading. 2012. No. 4. Pp. 84-105. (In Russ.)

Andreev A. N. Russian 'non-Russians' in 18 century and West Christianity influence. Bulletin of the South Ural State University. Series 'Social Sciences and the Humanities'. 2010. Vol. 15. No. 28 (204). Pp. 6-11. (In Russ.)

Andreev A. N. The priesthood of Roman Catholic church in the 'Greek township' of St. Petersburg. Bulletin of the South Ural State University. Series 'Social Sciences and the Humanities'. 2014. Vol. 14. No. 4. Pp. 6-14. (In Russ.)

Beltramini E. Roman Catholic government and mission to Tibet: a historical and theological study. International Bulletin of Mission Research. 2021. Vol. 45. No. 1. Pp. 68-72. (In Russ.)

Cholakyan A. Syrian Catholics of Armenian descent. 21-y vek: Informatsionno-analiticheskiy zhurnal. 2012. No. 2 (22). Pp. 53-68. (In Russ.)

Dzhundzhuzov S. V., Lyubichankovsky S. V. The missionary activity of Nicodemus Lenkeevich in the Kalmyk Khanate (1725-1734). The New Historical Bulletin. 2017. No. 3 (53). Pp. 172-191. (In Russ.)

Kalchenko A., Ven. History of origin and development of Catholic monastical missions in Russia. In: Transactions of Belgorod Theological Seminary. Collected scholarly papers. Vol. 7. Belgorod: LitKaraVan, 2018. Pp. 154-162. (In Russ.)

Kidirniyazov D. S., Lysenko Yu. M. Ossetian Theological Committee in the North Caucasus, $18^{\text {th }}$ to mid-19 ${ }^{\text {th }}$ centuries. Voprosy Istorii. 2015. No. 3. Pp. 163-169. (In Russ.)

Kuznetsov N. D. Administering foreign faiths in Russia: a historical perspective. Vremennik Demidovskogo yuridicheskogo litseya. 1898. Vol. 75. Pp. 65-104. (In Russ.)

Mackiewicz W. (OFM Conv) History of Catholic Church in Astrakhan Lands. Astrakhan: Novaya Liniya, 2012. 245 p. (In Russ.)

Maksimov A. S. From ethnocentrism to inculturation. Culture and civilization in the history of catholic mission. St. Tikhon's University Review. Series I: Theology. Philosophy. Religious Studies. 2015. No. 5 (61). Pp. 9-26. (In Russ.)

Ryazhev A. S. Grand Duchess Catherine and the Catholic missionaries in Southern Russia: the future Empress in search of paths to power (the second half of the 1750s). The New Historical Bulletin. 2020. No. 2. Pp. 6-22. (In Russ.) 


\section{История}

Ryazhev A. S. Religious policy of Russian 'enlightened absolutism': history of exploration reviewed. In: Sakharov A. N. (ed.) History and Historians 2005: A Historiographical Bulletin. Moscow: Nauka, 2006. Pp. 84-126. (In Russ.)

Ryazhev A. S. Unpublished documents on sending of a Christened captive to the Khan of Baku: an insight into correspondence between Holy Synod and Board of Foreign Affairs, 1777. Magna adsurguit: historia studiorum. 2017. No. 1. Pp. 32-40. (In Russ.)

Savvinsky I., Ven. Armenians in Astrakhan Eparchy, and Attitudes of Local Bishops towards Them, $18^{\text {th }}$ Century. Astrakhan: V. L. Egorov, 1900. [2], 106 p. (In Russ.)

Savvinsky I., Ven. Astrakhan Eparchy over the 300 Years of Its Existence: A Historical Note, 1602 to 1902. Astrakhan: V. L. Egorov, 1903. 403, [2] p. (In Russ.)

Savvinsky I., Ven. Catholics and Lutherans in Astrakhan Eparchy, and Attitudes of the Holy Synod and Local Eparchial Officials towards Them. Astrakhan: V. L. Egorov, 1902. 61 p. (In Russ.)

Tolstoy D. A. Roman Catholicism in Russia: A Historical Study by Count Dmitry A. Tolstoy. Vol. 1. St. Petersburg: V. F. Demakov, 1876. VIII, 538 p. (In Russ.)

Yangel T. Ya., Oglezneva G. V. Proselytism motives of interfaith relations in Russia in the second half of the XIX century. The Bulletin of Irkutsk State University. Series 'Political Science and Religious Studies'. 2016. Vol. 18. Pp. 204-211. (In Russ.) 